\title{
PENGARUH PERILAKU KEWIRAUSAHAAN TERHADAP KINERJA USAHATANI KARET DI PROVINSI JAMBI
}

\author{
Refa'ul Khairiyakh ${ }^{1 *}$, Elwamendri ${ }^{2}$, Dwi Nurul Amalia ${ }^{3}$ \\ ${ }^{1}$ Program Studi Agribisnis, Fakultas Pertanian Universitas Sebelas Maret \\ Jl. Ir. Sutami 36A, Kentingan, Surakarta \\ ${ }^{2,3}$ Program Studi Agribisnis, Fakultas Pertanian, Universitas Jambi \\ Jl. Lintas Jambi-Muara Bulian, Muaro Jambi, Jambi \\ *Corresponding author: refaul.khairiyakh@staff.uns.ac.id
}

\begin{abstract}
This study aims to determine the effect of entrepreneurship behavior on the performance of rubber in Jambi Province. This research was conducted in rubber production center area in Jambi Province. The selected locations are Batanghari and Muaro Jambi Region. The location was chosen purposively with the consideration that the two regions are rubber development areas based on the rubber development masterplan of Jambi Province. Selection of villages was with the same characteristics of sub-districts, and villages that resulted in the largest production of smallholder rubber. The method of analysis that used was Structural Equation Modeling (SEM). SEM analysis is a development or combination of several multivariate techniques. SEM applications are primarily intended to derive structural models. From the results of the study note that entrepreneurship behavior of farmers affect the performance of rubber farming. The indicator of the latent variable of entrepreneurship that has the greatest value is the acceptance of risk. Meanwhile, the latent variable indicator for farming performance with the biggest loading factor is income.
\end{abstract}

Keywords: entrepreneurship, performance of rubber farming, SEM

\begin{abstract}
Abstrak: Penelitian ini bertujuan untuk mengetahui pengaruh perilaku kewirausahaan terhadap kinerja usahatani karet di Provinsi Jambi. Lokasi yang dipilih yaitu Kabupaten Batanghari dan Kabupaten Muaro Jambi. Lokasi dipilih secara purposive dengan pertimbangan bahwa kedua wilayah merupakan wilayah pengembangan karet berdasarkan masterplan pengembangan karet Provinsi Jambi. Pemilihan kecamatan dan desa dengan karakteristik yang sama yaitu kecamatan dan desa yang menghasilkan produksi karet rakyat terbesar. Metode analisis yang digunakan adalah Structural Equation Modelling (SEM). Dari hasil penelitian diketahui bahwa perilaku kewirausahaan petani berpengaruh terhadap kinerja usahatani karet. Indikator variabel laten kewirausahaan yang memiliki nilai terbesar adalah penerimaan terhadap risiko. Sementara itu, indikator variabel laten untuk kinerja usahatani dengan nilai loading faktor terbesar adalah pendapatan.
\end{abstract}

Kata Kunci: kewirausahaan, kinerja usahatani karet, SEM

\section{PENDAHULUAN}

Karet merupakan salah satu komoditas perkebunan yang memberikan kontribusi pada proses pembangunan. Komoditas karet memiliki peranan penting yaitu sebagai sumber devisa, penyerap tenaga kerja, dan sumber pendapatan petani. Keunggulan komoditas karet dibandingkan komoditas lainnya adalah dapat tumbuh pada berbagai jenis kondisi dan jenis lahan, dapat membentuk ekologi hutan, dapat memberikan pendapatan harian bagi petani yang mengusahakannya. Berdasarkan data Ditjenbun (2017), secara umum luas areal perkebunan karet di Indonesia menunjukkan 
peningkatan sejak tahun 1980-2016, dengan rata-rata pertumbuhan sebesar $1,20 \%$ pertahun.

Provinsi Jambi merupakan salah satu penghasil karet yang berkontribusi dalam produksi karet nasional. Pada tahun 2016 luas lahan perkebunan karet di Provinsi Jambi mencapai $455.500 \mathrm{Ha}$ dengan produksi mencapai 319.900 Ton. Luas lahan dan produksi karet di Provinsi Jambi mengalami fluktuasi sejak tahun 2011 hingga 2016. Hal ini terkait dengan adanya perkebunan karet tua dan program replanting perkebunan karet yang sedang dilaksanakan oleh pemerintah Provinsi Jambi. Luas lahan dan produksi karet Provinsi Jambi tahun 2011 hingga 2016 secara rinci disajikan pada tabel 1 .

Tabel 1. Luas Lahan dan Produksi Karet Provinsi Jambi Tahun 2011-2016

\begin{tabular}{ccc}
\hline Tahun & $\begin{array}{c}\text { Luas Lahan } \\
\text { (Ribu Hektar) }\end{array}$ & $\begin{array}{c}\text { Produksi } \\
\text { (Ribu Ton) }\end{array}$ \\
\hline 2011 & 444.50 & 319.90 \\
2012 & 450.87 & 322.38 \\
2013 & 384.78 & 270.25 \\
2014 & 378.00 & 262.20 \\
2015 & 379.00 & 260.60 \\
2016 & 374.90 & 283.10 \\
\hline
\end{tabular}

Luas lahan perkebunan karet di Provinsi Jambi didominasi oleh perkebunan rakyat. Berdasarkan data BPS Provinsi Jambi (2019) terdapat 25.6256 jiwa petani karet yang tersebar di 9 kabupaten. Data jumlah petani karet berdasarkan kabupaten di Provinsi Jambi pada tahun 2011 hingga 2015 disajikan pada tabel 2. Besarnya jumlah petani karet di Provinsi Jambi yang disajikan pada tabel 2 menunjukkan bahwa komoditas karet masih menjadi sumber pendapatan petani di Provinsi Jambi. Peran komoditas karet sebagai sumber pendapatan membuat petani diharuskan dapat terus meningkatkan kinerja usahatani karetnya.

Menurut Priyanto (2004), kemampuan petani dalam melakukan pengelolaan dan mengkreasikan faktor produksi menjadi sebuah usaha yang mendatangkan keuntungan dan berkelanjutan sangat dipengaruhi oleh entrepreneurial opportunity sehingga mampu membentuk pengetahuan, motivasi, inisiatif, kreasi, dan kompetensi dalam diri seseorang dalam berusaha. Keberhasilan petani mecapai kinerja usahatani yang tinggi tidak hanya ditentukan oleh kegiatan budidaya tetapi juga oleh potensi internal petani salah satunya adalah kewirausahaan.

Sumber: BPS, 2019

Tabel 2. Jumlah Petani Karet di Provinsi Jambi Tahun 2011-2015

\begin{tabular}{lrrrrr}
\hline \multirow{2}{*}{ Kabupaten/Kota } & \multicolumn{5}{c}{ Jumlah Petani Karet (Jiwa) } \\
\cline { 2 - 6 } Kerinci & 2015 & 2014 & 2013 & 2012 & 2011 \\
\hline Merangin & 1377 & 1274 & 1274 & 1274 & 1271 \\
Sarolangun & 54317 & 54581 & 54581 & 54581 & 54581 \\
Batang Hari & 35401 & 34849 & 34914 & 33113 & 31185 \\
Muaro Jambi & 38897 & 38859 & 38820 & 3811 & 38733 \\
Tanjab Timur & 15220 & 15910 & 15190 & 15118 & 14951 \\
Tanjab Barat & 5266 & 5264 & 5264 & 5264 & 5106 \\
Tebo & 6078 & 6395 & 5960 & 5945 & 5764 \\
Bungo & 53759 & 54126 & 54044 & 53678 & 53641 \\
Kota Jambi & 45941 & 45394 & 44766 & 44758 & 44746 \\
Sungai Penuh & 0 & 0 & 0 & 0 & 0 \\
\hline Total & 0 & 0 & 0 & 0 & 0 \\
\hline
\end{tabular}

Sumber: BPS Provinsi Jambi, 2019 
Menurut Daryanto (2009), kewirausahaan merupakan kemampuan untuk menciptakan dan meny

ra membaca dan mengutip dari berbagai literatur yang berkaitan dengan permasalahan yang akan diteliti, laporan dan jurnal dari instansi pemerintahan.

Petani karet yang dijadikan sampel adalah sebanyak 100 petani. Hal ini mengacu pada Hair, et al (1995) yang menyatakan bahwa ukuran sampel yanediakan produk yang bernilai tambah dengan menerapkan cara kerja yang efisien, melalui keberanian mengambil risiko, kreatifitas, dan inovasi serta kemampuan manajemen untuk mencari dan membaca peluang yang ada.

Sifat kewirausahaan adalah sifat yang berkaitan dengan kemampuan melihat dan menilai kesempatan-kesempatan atau peluang usaha serta kemampuan mengoptimalkan sumberdaya dan mengambil tindakan serta bermotivasi tinggi dalam mengambil risiko sebagai usaha untuk mensukseskan usahanya. Kewirausahaan menjadi penting untuk diteliti karena dimasa yang akan datang petani dengan berbagai keterbatasan baik keterbatasan lahan, teknologi, modal, manajemen, informasi, dan akses pasar, petani harus tetap berusaha untuk mencapai kinerja usahatani yang tinggi (Nurdiani, 2015).

Menurut

Soetriono

(2006), kewirausahaan penting untuk pengembangan agribisnis. Hal ini sejalan dengan pendapat Priyanto (2004) yang menyatakan bahwa kewirausahaan penting pada proses pembangunan ekonomi termasuk pembangunan pertanian. Tekanan lingkungan pada sektor pertanian yang memasuki era perdagangan bebas internasional membutuhkan wirausaha dibidang pertanian yang mampu bersaing untuk menjawab tantangan dan peluang yang ada.

Berdasarkan usarain diatas diketahui kewirausahaan menjadi sangat penting sebagai salah satu upaya baru dalam meningkatkan kinerja usahatani. Tujuan penelitian ini ialah untuk mengetahui pengaruh perilaku kewirausahaan terhadap kinerja usahatani karet di Provinsi Jambi.

\section{METODE PENELITIAN}

Lokasi penelitian dipilih secara purposive dengan pertimbangan bahwa Kabupaten Batang
Hari dan Kabupaten Muaro Jambi merupakan wilayah pengembangan perkebunan karet di Provinsi Jambi berdasarkan Kepmentan No. 46/2015 tentang Penetapan Lokasi Kawasan Perkebunan Nasional.

Data yag digunakan pada penelitian merupakan data primer dan data sekunder. Data primer merupakan data yang dikumpulkan secara langsung oleh peneliti dari responden atau dalam penelitian ini dari petani karet. Metode pengumpulan data primer dalam penelitian ini adalah metode observasi dan wawancara langsung. Observasi yaitu pengamatan dan penelitian langsung ke patani karet. Sementara itu, Data sekunder merupakan struktur data historis mengenai variabelvariabel yang telah dikumpulkan dan dihimpun sebelumnya oleh pihak lain. Metode pengumpulan data sekunder yaitu dengan menggunakan cag sesuai untuk SEM adalah 100-200 atau sebanyak 5-100 kali jumlah parameter yang diestimasi.

Data yang diperolah dianalisis dengan menggunakan Structural Equation Modelling (SEM) dengan menggunakan program Amos. Analisis SEM merupakan pengembangan atau kombinasi dari beberapa teknik multivariate terutama multiple regression dan analisis faktor. SEM digunakan untuk menguji suatu rangkaian hubungan saling ketergantungan antar variabel secara simultan. Aplikasi model SEM secara bersama akan dipergunakan untuk (1) pemeriksaan validitas dan reliabilitas, (2) pemeriksaan model hubungan antar variabel laten, (3) mendapatkan model yang bermanfaat untuk prediksi

\section{HASIL DAN PEMBAHASAN}

\section{Kondisi Geografis}

Penelitian dilakukan didua Kabupaten di Provinsi Jambi, yaitu Kabupaten Batang Hari dan Kabupaten Muaro Jambi. Dalam lingkup Provinsi Jambi, Kabupaten Batang Hari berada di wilayah bagian tengah Provinsi dan daerah perbukitan. Kabupaten Batang Hari berbatasan dengan Kabupaten Tanjung Jabung Barat di sebelah utara, Kabupaten Sarolangun dan Provinsi Sumatera Selatan di sebelah selatan, Kabupaten Muaro Jambi di sebelah timur, dan Kabupaten Tebo di sebelah barat. Kabupaten Muaro Jambi merupakan daerah dataran rendah dengan ketinggian dari permukaan laut 0 
hingga 300 meter. Kabupaten Muaro Jambi berbatasan dengan Kabupaten Tanjung Jabung Barat disebelah utara, Provinsi Sumatera Selatan di sebelah selatan, Kabupaten Batang Hari di sebelah barat, dan Kabupaten Tanjung Jabung Timur di sebelah timur.

\section{Karakteristik Petani Karet}

Karakteristik individu merupakan bagian dari pribadi yang melekat pada setiap individu. Karakteristik akan mempengaruhi tingkah laku individu dalam berbagai situasi dan kondisi termasuk dalam situasi kerja (Rogers dan Shoemaker, 1971 dalam Damihartini dan Jahi, 2005). Karakteristik petani karet dalam penelitian ini adalah umur petani, tingkat pendidikan formal, status kepemilikan lahan, jumlah anggota keluarga, dan keanggotaan pada kelompok tani.

Bedasarkan tabel 3 diketahui bahwa 98,33\% petani karet di Provinsi Jambi berada pada usia produktif. Usia produktif adalah usia ketika seseorang dianggap dapat berproduksi atau menghasilkan sesuatu dengan ciri-ciri memiliki karya, aktif, energik dalam bekerja, kerja keras, kerja cerdas, bersikap mandiri, tidak mengabaikan spiritual dan religiusitas, memiliki pandangan hidup dan wawasan ke depan. Dari segi pengusaan lahan, $72,2 \%$ petani di daerah penelitian merupakan petani dengan status penguasaan lahan sebagai petani pemilik. Status penguasaan lahan penting diketahui karena berdasarkan status penguasaan lahan ini akan menentukan bagaimana petani karet melakukan pengelolaan terhadap usahataninya. Menurut Manatar dkk (2017), status penguasaan lahan akan mempengaruhi pendapatan suatu usahatani.

Jumlah anggota keluarga petani karet di daerah penelitian yang menjadi tanggungan berkisar 1 hingga 6 orang. Berdasarkan tabel 3 diketahui bahwa $73,33 \%$ petani karet di Provinsi Jambi memiliki anggota keluarga antara $3-4$ orang. Sinungan (1987) menyatakan bahwa anggota keluarga yang menjadi tanggungan akan meningkatkan kemauan untuk bekerja lebih baik, karena kebutuhan akan terpenuhi jika seseorang bekerja dengan baik sehingga mampu menghasilkan penerimaan yang menunjang kebutuhan keluarga.

Kelompok tani memberikan wadah bagi petani untuk bertukar informasi dan melakukan kegiatan pendidikan non formal dalam rangkat peningkatan kinerja usahatani. Namun demikian, tidak semua petani menganggap penting untuk ikut tergabung dalam suatu kelompok tani. Terdapat $75 \%$ petani karet di daerah penelitian (Tabel 3) yang tidak tergabung dalam kelompok tani.

Tabel 3. Karakteristik Petani Sampel

\begin{tabular}{|c|c|c|c|}
\hline No & Umur (Tahun) & Jumlah (KK) & Persentase (\%) \\
\hline 1 & $0-14$ (Belum Produktif) & 0 & 0 \\
\hline 2 & 15-64 (Produktif) & 118 & 98,33 \\
\hline 3 & $\geq 65$ (Tidak Produktif) & 2 & 1,67 \\
\hline No & Tingkat Pendidikan & Jumlah (KK) & Persentase (\%) \\
\hline 1 & Tidak Tamat SD & 8 & 6,67 \\
\hline 2 & $\mathrm{SD}$ & 48 & 40 \\
\hline 3 & SMP & 36 & 30 \\
\hline 4 & SMA & 27 & 22,5 \\
\hline 5 & Perguruan Tinggi & 1 & 0,83 \\
\hline No & Status Kepemilikan Lahan & Jumlah (KK) & Persentase $(\%)$ \\
\hline 1 & Petani Pemilik & 95 & 79,20 \\
\hline 2 & Petani Penggarap & 25 & 20.80 \\
\hline No & Jumlah Anggota Keluarga (Orang) & $\begin{array}{c}\text { Jumlah } \\
\text { (KK) }\end{array}$ & $\begin{array}{c}\text { Persentase } \\
(\%)\end{array}$ \\
\hline 1 & $1-2$ & 21 & 17,50 \\
\hline 2 & $3-4$ & 88 & 73,33 \\
\hline 3 & $5-6$ & 11 & 9,17 \\
\hline No & Keanggotaan & Jumlah (KK) & Persentase (\%) \\
\hline 1 & Anggota Kelompok Tani & 42 & 35 \\
\hline 2 & Bukan Anggota Kelompok Tani & 78 & 75 \\
\hline
\end{tabular}

Sumber: Analisis Data Primer, 2017 


\section{Kewirausahaan Petani}

Menurut Bird dan Schjoedt (2009), perilaku kewirausahaan merupakan bagian penting di dalam proses kewirausahaan, dimana perilaku kewirausahan merupakan perilaku manusia dalam mengindentifikasi dan mengeksplitasi peluang melalui pembentukan dan pengembangan usaha. Menurut Skiner (Irwanto et al, 1996) perilaku dapat dibedakan menjadi perilaku alami dan berilaku operan. Perilaku alami adalah perilaku yang dibawa sejak lahir yaitu berupa refleks dan insting, sementara itu perilaku operan adalah perilaku yang dibentuk sehingga perilaku tersebut dapat berubah sesuai melalui suatu proses belajar. Terdapat delapan karakteristik kewirausahaan yaitu; memiliki rasa tanggung jawab atas usahanya, berani mengambil risiko dalam menjalankan usahanya, percaya diri untuk berhasil, memiliki semangat dan kerja keras untuk mengembangkan usahanya, berorientasi ke depan, keterampilan dalam pengelolaan, memiliki keinginan untuk berprestasi (Suryana, 2003).

Berdasarkan Tabel 4 diketahui bahwa 44,16\% petani karet di Provinsi Jambi memiliki kebutuhan prestasi yang rendah. Rendahnya kebutuhan berprestasi dapat menjadi tolak ukur bahwa petani memiliki motivasi yang rendah untuk mengelola usahatani karetnya lebih baik. Sebanyak 43,33\% petani karet memiliki tingkat penerimaan terhadap risiko yang rendah. Sementara itu $59 \%$ petani memiliki tingkat kreativitas yang sangat tinggi. Hal ini berarti petani karet di Provinsi Jambi memiliki sifat ingin mencoba hal baru untuk meningkatkan kinerja usahataninya

\section{Kinerja Usahatani Karet}

Umumnya kinerja usahatani diukur melalui produktivitas, harga, dan pendapatan (Suratiyah, 2011). Petani sebagai pengelola mengharapkan produksi yang tinggi sehingga memperoleh pendapatan yang tinggi pula. Pada penelitian ini, kinerja usahatani diukur dengan variabel produktivitas dan pendapatan. Kinerja usahatani karet di daerah penelitian dijabarkan pada Tabel 5.

Produktivitas dan pendapatan yang tinggi merupakan tujuan yang dicapai oleh petani. Berdasarkan Tabel 5 dapat diketahui bahwa produktivitas terendah usahatani karet di daerah penelitian adalah 0,54 ton/ha/tahun, dan produktivitas tertinggi adalah 6 ton/ha/tahun dengan rerata 1,6 ton/ha/tahun. Sementara itu, ukuran lain kinerja adalah pendapatan usahatani. Rerata pendapatan petani karet di Provinsi Jambi adalah Rp 11.523.778/ha/Tahun.

\section{Pengaruh Perilaku Kewirausahaan terhadap Kinerja Usahatani Karet}

Stuctural Equation Model merupakan suatu teknik statistik yang mampu menganalisis pola hubungan antara variabel laten dan indikatornya, variabel laten yang satu dengan

Tabel 4. Tingkat Perilaku Kewirausahaan Petani Karet di Daerah Penelitian Tahun 2017

\begin{tabular}{lccccc}
\hline \multirow{2}{*}{\multicolumn{1}{c}{ Indikator }} & \multicolumn{5}{c}{ Distribusi Petani (\%) } \\
\cline { 2 - 6 } & 1 & 2 & 3 & 4 & 5 \\
\hline Kebutuhan Berprestasi & 44,16 & 20,00 & 11,67 & 6,67 & 17,50 \\
Independensi & 0,00 & 23,33 & 16,67 & 30,83 & 29,17 \\
Penerimaan terhadap Risiko & 10,00 & 43,33 & 11,67 & 24,17 & 10,83 \\
Kreativitas & 5,00 & 6,66 & 20,00 & 9,17 & 59.17 \\
Pengetahuan Usahatani & 15,83 & 26,67 & 11,67 & 12,50 & 33,33 \\
Orientasi Pasar & 8,33 & 38,33 & 20,00 & 9,17 & 24,17 \\
\hline
\end{tabular}

Sumber: Analisis Data Primer, 2017

Keterangan: 1, 2, 3, 4, 5 = Skala Likert

Tabel 5. Kinerja Usahatani Karet di Daerah Penelitian Tahun 2017

\begin{tabular}{lccc}
\hline \multirow{2}{*}{ Indikator } & \multicolumn{3}{c}{ Kinerja } \\
\cline { 2 - 4 } & Minimum & Maksimum & Rata-rata \\
\hline Produktivitas (Ton/Ha/Tahun) & 0,54 & 6 & 1,6 \\
Pendapatan (Rp/Ha/Tahun) & 1257300 & 46990625 & 11523778 \\
\hline
\end{tabular}

Sumber: Analisis Data Primer, 2017 
yang lainnya, serta kesalahan pengukuran secara langsung. Stuctural Equation Model mempunyai kemampuan untuk mengestimasi hubungan antar variabel yang bersifat multiple relationship. Hubungan ini dibentuk dalam model struktural (hubungan antara variabel laten dependen dan independen). Stuctural Equation Model juga mampu untuk menggambarkan pola hubungan antara konstrak laten (unobserved) dan variabel manifest (variabel indikator) (Yamin dan Kurniawan, 2009).

Analisis SEM dilakukan setelah pengembangan suatu model dalam bentuk path diagram. Pengembangan ini dilakukan berdasrkan teori-teri yang yang telah ada sebelumnya. Pengembangan path diagram bertujuan untuk mempermudah dalam pemahaman hubungan antar variabel pada model. Model tersebut kemudian diestimasi untuk memperoleh nilai atau koefisien yang ada dalam model. Metode estimasi yang digunakan yaitu maximum likelihood. Hasil SEM yang telah diestimasi dalam hasil estimasi berupa standardized solution dapat dilihat pada Gambar 1.

Model dengan hasil estimasi standardized solution seperti pada gambar digunakan untuk mengetahui keeratan hubungan antar variabel dalam model. Pada model pengukuran dapat diketahui besaran muatan faktor (factor loading) yang menunjukkan seberapa kuat variabel indikator merefleksikan atau mengukur setiap variabel laten, baik variabel laten eksogen maupun variabel laten endogen. Sementara itu, pada model struktural dapat diketahui besaran koefisien gamma dan beta untuk memperlihatkan keeratan hubungan antar variabel laten.

Setelah model mengalami respesifikasi, maka selanjutnya model tersebut diuji kembali kecocokannya. Pengujian ini dilakukan dengan mencocokkan kriteria ukuran kecocokan absolut, ukuran kecocokan inkremental, dan ukuran kecocokan parsimoni yang sudah ditetapkan dengan hasil goodness of fit statistics. Ukuran RMSEA model tersebut masih poor fit, namun GFI sudah memperlihatkan kriteria good fit. Dengan demikian, ukuran kecocokan absolut model sudah cukup baik dalam menggambarkan data empiris.

Indikator NFI, TLI, dan RFI model telah margina fit. Sementara itu, untuk indikator CFI dan IFI model telah mencapai good fit. Ukuran normed chi-square pada uji kecocokan ukuran parsimonious fit measures (ukuran kecocokan parsimoni) model mempunyai nilai sebesar 59,59. Nilai tersebut berada pada diatas abang batas nilai yakni 3,0,. Ukuran GOF dengan kriteria good fit seperti normed chi-square,

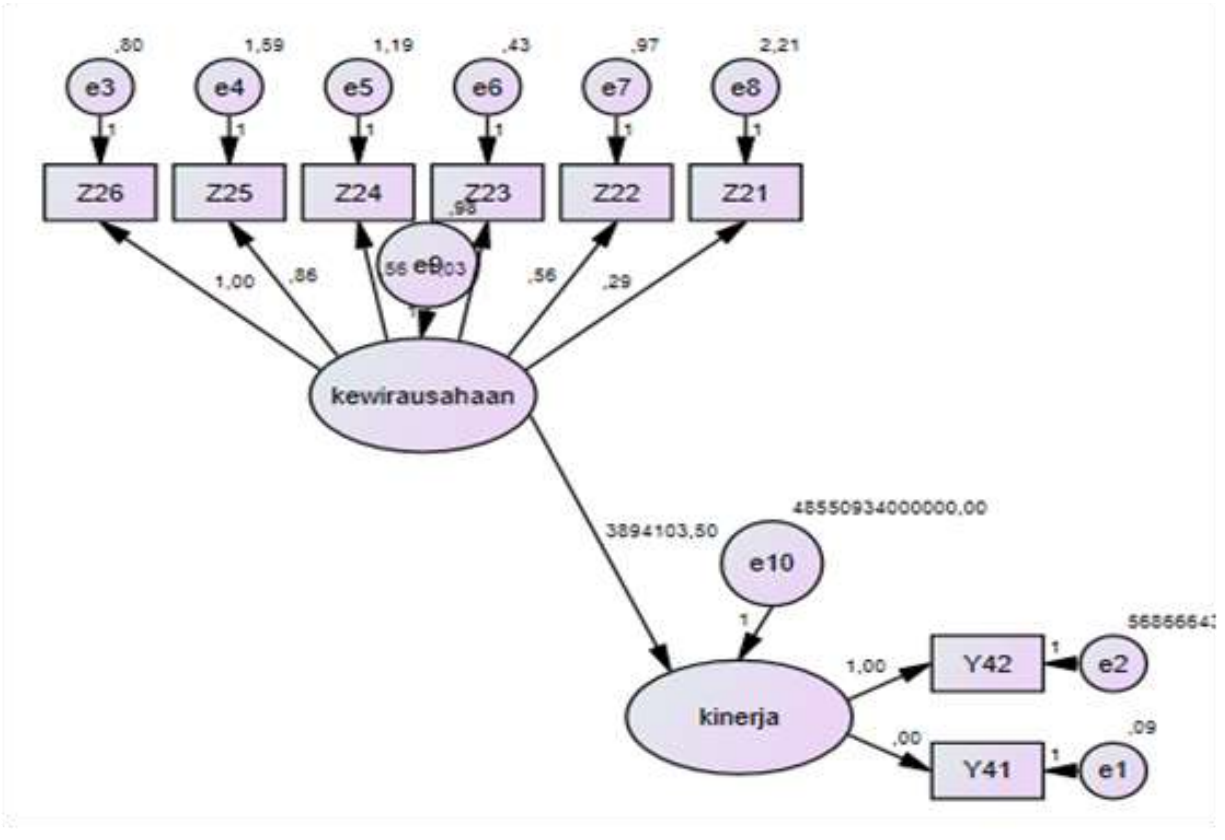

Gambar 1. Path Diagram Pengaruh Perilaku Kewirausahaan terhadap Kinerja Usahatani Karet 
Tabel 6. Hasil Regresi Pengaruh Perilaku kewirausahaan terhadap Kinerja Usahatani di Daerah Penelitian Tahun 2017

\begin{tabular}{lrlrrrr}
\hline \multicolumn{1}{c}{} & & Estimate & S.E. & C.R. & P \\
\hline kinerja & $<---$ & Kewirausahaan & 3956800,831 & 835726,309 & 4,735 & $* * *$ \\
Y42 & $<---$ & Kinerja & 1,000 & & & $* * *$ \\
Y41 & $<---$ & Kinerja & 0,000 & 0,000 & 12,532 & \\
Z26 & $<---$ & Kewirausahaan & 1,000 & & & $* * *$ \\
Z25 & $<---$ & Kewirausahaan & 0,853 & 0,153 & 5,569 & $* * *$ \\
Z24 & $<---$ & Kewirausahaan & 0,562 & 0,123 & 4,568 & $* * *$ \\
Z23 & $<---$ & Kewirausahaan & 1,002 & 0,134 & 7,478 & $* * *$ \\
Z22 & $<---$ & Kewirausahaan & 0,542 & 0,114 & 4,774 & $*$.
\end{tabular}

Sumber: Analisis Data Primer, 2017

Keterangan: $* * *$ signifikan pada $\alpha 0,01$

memperlihatkan bahwa model mempunyai parsimoni atau kehematan tinggi karena model memiliki parameter relatif sedikit dengan DF yang relatif banyak. Ukuran CFI dan IFI juga memiliki kriteria good fit memperlihatkan bahwa tingkat kecocokan model-data dari model yang diusulkan mendekati saturated model (best fit) dibandingkan dengan independence model (worst fit) pada model dasar.

Berdasarkan Tabel 6, diketahui bahwa perilaku kewirausahaan secara statistik signifikan mempengaruhi kinerja usahatani karet. Hal ini ditunjukkan oleh nilai C.R yang > 1.96. kondisi tersebut menunjukkan bahwa semakin meningkatnya perilaku kewirausahaan yang dicerminkan oleh indenpedensi (Z22), penerimaan terhadap risiko (Z23), kreativitas (Z24), pengetahuan akan usahatani (Z25), dan orientasi pasar (Z26), maka semakin baik kinerja ushatani karet di Provinsi Jambi. Jadi secara keseluruhan karakteristik individu dan lingkungan bisnis secara konstruk mempengaruhi perspektif petani terhadap kinerja usahatani karet melalui perilaku kewirausahaan. Hasil regresi pada tabel 6 juga menunjukkan bahwa indikator yang digunakan telah valid untuk variabel yang digunakan pada model. Hal ini terlihat dari nilai C.R yang dua kali atau lebih dari nilai S.E.

Kontribusi lima indikator yaitu indenpedensi, penerimaan terhadap risiko, kreativitas, pengetahuan akan usahatani, dan orientasi pasar dapat diketahui melalu nilai loading faktor seperti yang tampilkan pada Tabel 7. Semakin besar nilai loading faktor maka semakin besar kontribusi untuk indikator tersebut.
Tabel 7. Loading Factor Indikator terhadap Variabel Laten

\begin{tabular}{|c|c|c|}
\hline Indikator & Laten & Estimate \\
\hline Pendapatan & kinerja & 0,958 \\
\hline Produktivitas & kinerja & 0,970 \\
\hline orientasi pasar & kewirausahaan & 0,752 \\
\hline $\begin{array}{l}\text { pengetahuan } \\
\text { akan usahatani }\end{array}$ & kewirausahaan & 0,562 \\
\hline kreativitas & kewirausahaan & 0,460 \\
\hline $\begin{array}{l}\text { penerimaan } \\
\text { terhadap risiko }\end{array}$ & kewirausahaan & 0,826 \\
\hline indenpedensi & kewirausahaan & 0,481 \\
\hline
\end{tabular}

Sumber: Analisis Data Primer, 2017

Pada Tabel 7 dapat dilihat bahwa nilai loading faktor tertinggi untuk perilaku kewirausahaan adalah penerimaan terhadap risiko dengan nilai 0,82 . Usahatani merupakan usaha yang memiliki banyak risiko. Salah satu risiko adalah ketidakpastian iklim, sehingga petani harus selalu siap menerima segala bentuk risiko dalam berusahatani. Indikator yang memiliki nilai terkecil adalah kreativitas dan indenpedesi, yaitu kurang dari 0,5. Sementara itu, indikator untuk kinerja usahatani adalah pendapatan dan produktivitas dimana nilai estimate loading faktornya adalah 0,95 dan 0,97 . Hal ini menunjukkan bahwa kedua indikator tersebut mencerminkan kinerja usahatani karet di Provinsi Jambi.

\section{KESIMPULAN DAN SARAN}

Perilaku kewirusahaan petani karet di Provinsi Jambi ditunjukkan oleh sikap petani yaitu indenpedensi, penerimaan terhadap risiko, kreativitas, pengetahuan akan usahatani, dan orientasi pasar. Perilaku kewirausahaan petani berpengaruh terhadap kinerja usahatani karet. 
Hal ini berarti bahwa semakin baik perilaku kewirausahaan petani karet akan meningkatkan kinerja usahatani karet di Provinsi Jambi.

Peningkatan kinerja petani karet di Provinsi Jambi dapat dilakukan melalui peningkatan sikap wirausaha petani karet itu sendiri. Pemerintah Provinsi Jambi dapat melakukannya dengan berbagai program peningkatan kapasitas petani karet khususnya kewirausahaan.

\section{DAFTAR PUSTAKA}

Bird, B., dan Schjoedt. 2009. Entrepreneurial Behavior: Its Nature, Scope, Recent Research, and Agenda for Future Research. In A.L Carsrud \& M. Brannback (Eds), Understanding the Entrepreneurial Mind. New York: Springer.

BPS. (2019/08/01). Tabel Dinamis Perkebunan. Retrieved from https://www.bps.go.id/subject/54/perkeb unan.html\#subjekViewTab6

BPS Provinsi Jambi. (2019/08/01). Tabel Dinamis Perkebunan. Retrieved from https://jambi.bps.go.id/subject/54/perkeb unan.html\#subjekViewTab5

Damihartini, R.S dan Jahi, A, 2005. Hubungan Karakteristik Petani dengan Kompetensi Agribisnis pada Usahatani Sayuran di Kabupaten Kediri Jawa Timur. Jurnal Penyuluhan, 1 (1), 41-48

\section{Daryanto, 2009. Panduan Proses Pembelajaran Kreatif dan Inovatif. Jakarta: AV Publisher}

Ditjenbun. 2017. Statistik Perkebunan Indonesia 2015-2017 Karet. Sekretariat
Direktorat Jendral Perkebunan, Kementerian Pertanian.

Hair, J. F, Black, W.C , Babin, B.J., Anderson, R. E. 995. Multivariate Data Analysis With Reading, Fourt Edition, New Jersey: Prentice Hall.

Irwanto. 1996. Psikologi Umum. Jakarta: Gramedia Pustaka.

Manatar M.P., E.H. Loah, dan J.R. Mandei. 2017. Pengaruh Status Penguasaan Lahan terhadap Pendapatan Petani Padi di Desa Jumani Kecamatan Maesaan Kabupaten Minahasa Selatan. Jurnal Agri-SosioEkonomi Unsrat, 13 (1), 5564.

Nurdiani, U., Hartono, S. dan Jamhari. 2015. Farmers Entrepreneurship and Performance of Red Onion Farming in Bantul District. Jurnal Ilmu Pertanian, 18 (2), 98-108.

Sinungan, M. 1987. Produktivitas: Apa dan Bagaimana. Jakarta: Bina Aksara. Jakarta.

Soetriono. 2006. Analisis Finansial dan Analisis Ekonomi, Daya Saing dalam Tinjauan Analisis. Malang: Bayu Media.

Suratiyah, K. 2011. Ilmu Usahatani. Bogor: Penebar Swadaya.

Suryana. 2003. Kewirausahaan Pedoman Praktis: Kiat dan Proses Menuju Sukses. Jakarta: Salemba Empat.

Yamin, S., dan Heri, K. 2009. SPSS Complete: Teknik Analisis Statistik Terlengkap dengan Software SPSS. Jakarta: Salemba Infotek. 